\title{
ENTREPRENEURIAL ORIENTATION AND SOCIAL CAPITAL IN PRICING STRATEGY: A CASE OF SMALL ENTERPRISES IN EAST JAVA
}

\author{
Suyanto \\ Fakultas Bisnis dan Ekonomika, Universitas Surabaya \\ suyanto@ubaya.ac.id \\ Aluisius Hery Pratono \\ Fakultas Bisnis dan Ekonomika, Universitas Surabaya \\ hery_pra@ubaya.ac.id
}

\begin{abstract}
ABSTRAK
Penelitian ini mengkaji dampak orientasi kewirausahaan dan modal insani terhadap strategi penetapan harga perusahaan-perusahaan kecil di Jawa Timur. Metoda penelitian ini merupakan campuran antara analisis kuantitatif dan analisis kualitatif yang dipergunaan untuk menganalisis 168 perusahaan kecil. Temuan utama dari analisis kualitatif adalah perusahaan kecil cenderung menetapkan harga rendah untuk produk-produk mereka, diskon diberikan kepada pelanggan yang loyal, sistem penetapan harga transfer berdasarkan biaya produksi, adanya hubungan yang dekat antara pekerja dan pemilik dan antar pekerja, serta keagresifan bukanlah merupakan ciri perusahaan kecil. Temuan utama dari analisis kuantitatif ada tiga, yaitu (1) keagresifan dalam inovasi produk dan otonomi dalam pengambilan risiko merupakan dua ukuran orientasi kewirausahaan yang memengaruhi kemampuan perusahaan kecil di Jawa Timur dalam menetapkan harga produk baru; (2) baik agresifitas dalam inovasi dan otonomi dalam pengambilan risiko menentukan program pemasaran (salah satu ukuran penetapan harga) di perusahaanperusahaan kecil; (3) berbagi ide tentang tujuan merupakan faktor kunci dalam modal insani yang sangat memengaruhi komunikasi yang baik dengan pelanggan.
\end{abstract}

Kata kunci: orientasi kewirausahaan, modal insani, strategi penetapan harga, perusahaan kecil

\section{INTRODUCTION}

The competition in pricing strategy among small enterprises has increased considerably in Indonesia and elsewhere. Small enterprises face market complexity while settling down themselves for survival in competition. Price strategy becomes important, as the consumers are price sensitive. The lack of mediating roles from the internal factors, such as formalization, centralization, cross-functional integration, and organizational commitment, force small enterprises to find alternative factors in 
supporting their capability in pricing strategy (Rubera and Kirca 2012). Entrepreneurial orientation and social capital has gained attention as two pivotal variables in determining price strategy (Al-Swidi and Mahmood 2012; Berzina 2011; Liu and Zhang 2013). As small businesses often suffer from performance enhancement due to economies of scale and group reputation effects, entrepreneurial orientation and social capital are alternative solutions for winning price competition (Carney et al., 2011 and Liozu et al., 2012).

The inability to produce within economies of scale has place small firms in a difficult position in competing with large-scale firms (Laforet 2009). Producing in small scale resulted in higher production costs in comparison with large-scale firms. The problem then arises about how the small firms survive and compete with other firms, particularly in prices. Two key alternatives for pricing strategy are the development of entrepreneurial orientation and the enhancement of social capital (Parkman et al., 2012; Wu et al., 2008). These two alternatives increase small firms' competitiveness.

Unfortunately, researches on entrepreneurship orientation and social capital are rare, as the two topics are relatively new and just developed in the early 2000. Empirical studies on the effects of the two variables on pricing strategy are even harder to find. A study by Liozu and Hinterhuber (2013) provides a ground for the possibility to examine price strategy from factors rather than value chain variables. This current study fills the gap in the literature by examining in a comprehensive perspective, though not only quantitative method but also qualitative method, on the impact of entrepreneurship orientation and social capital on the pricing strategy. By taking a case on small enterprises in East Java, Indonesia, it might shade a light on the importance of entrepreneurship orientation and social capital in improving the capacity of small firms in pricing strategy.

The main contribution of this current study rests on the combine analysis, both quantitative and qualitative analysis. The quantitative analysis focuses on answering the question about the indication of entrepreneurship orientation and social capital in increasing market share, while the qualitative analysis tries to answer on how these two factors increase market shares. The qualitative analysis complements the quantitative analysis in providing a different spectrum of findings.

\section{LITERATURE REVIEW}

\section{Pricing Strategy}

Pricing capability is a component of market power (Limehouse et al., 2012). Price capability determines a firm to set price for new products, communicate its products to customers, and develop marketing programs (Murray et al., 2011). The way of firm to implement its capability in determining prices is well-known as price 
strategy. According to Liozu et al. (2012), there are at least three types of pricing strategy, namely competitor-based pricing, value-based pricing, and cost-based pricing. Its type of pricing strategy has its own advantages and disadvantages, which is well known in the literature.

The cost-based pricing calculates the selling price by adding up all costs including profit. Many firms adopt this strategy in their intra-company trade and treat the inter-company trade as cost-based transfer pricing. Pfeiffer et al. (2011) indicates a range of different methods for cost-based transfer pricing, which are based on either standard or actual costs including mark-ups. While the rules and procedures of these methods have been extensively described, yet the efficiency and the precision of these methods are not well-informed. So that, the application of the cost-based pricing strategy is implemented under the condition that internal transfer pricing are included.

The competition-based pricing refers to prices of competing products, which used as a benchmark for setting a price. In a recent literature, Liu and Zhang (2013) introduces dynamic pricing competition between two firms that offer vertically differentiated products to potential customers whose are intertemporal utility maximisers. This dynamic competitive pricing is well known as skimming pricing, arising from a unique pure-strategy Markov perfect Equilibrium in the game under a simple condition. Kartono (2011) indicates that a firm might adopt a relative aggressive pricing when its products have fewer competitors.

The value-based pricing is defined as a price that depends on the customer willingness to pay (Liozu et al., 2012). The conceptualization of value-based pricing varies from firms to firms. Mostly, this pricing strategy influences by market knowledge and customers knowledge, which related to the deep understanding of customers' mind and competition (Piercy et al., 2010).

\section{Entrepreneurship Orientation}

Entrepreneurial orientation (EO) is associated with the way to run a business in the long term, in which firms may be able to enhance business performance. The theoretical and empirical inquiry of EO phenomenon has been emerging for over 30 years (Covin and Wales 2012). This concept is different from entrepreneurship, which is about how to set up a new business (Wang and Shi 2012). Although both concepts cover opportunity and resource effectiveness, the EO focuses more on responsive behavior upon market environment, which is consider to be opposite behavior to traditional and adaptive market orientation (Renko et al., 2009).

In entrepreneurship theory, there are at least two dominant strands. There are Kirznerian and Schumpeterian. Sundqvist et al. (2012) highlights that Kirzenerian considers discovery process over business possibilities, while innovation is associated with Schumpeterian entrepreneur. For Schumpeter, external variables are considered as uncontrollable factors at the micro-level, while the idea to seize 
opportunities spring from internally induced change (Bertta et al., 2010). In entrepreneurial orientation, the concept of Schumpeter's innovation becomes factor of entrepreneurial orientation, while discovery process proposed by Kirznerian is considered as proactiveness. The factor and items in the entrepreneurial orientation is summarized in Table 1. These items are used in formulating the questionnaire in this current research.

Table 1

Factor and items of Entrepreneurial Orientation

\begin{tabular}{|c|c|c|}
\hline Factors & Items & Sources \\
\hline Autonomy & $\begin{array}{l}\text { Work autonomously } \\
\text { Best result with autonomy decision } \\
\text { Without constantly referring to supervisor } \\
\text { Managers identify and select the opportunities }\end{array}$ & $\begin{array}{l}\text { Lumpkin et al. } \\
\text { (2009) }\end{array}$ \\
\hline Risk-taking behavior & $\begin{array}{l}\text { Proclivity for high risk project } \\
\text { Bold and wide ranging act } \\
\text { Obtain financing for new business } \\
\text { Without adequate resource } \\
\text { Aim to high growth } \\
\text { "Wait and see" posture (R) } \\
\text { Study problem carefully (R) } \\
\text { Quick to spend resource }\end{array}$ & $\begin{array}{l}\text { Kropp et al. (2008), } \\
\text { Gürbüz and Aykol } \\
\text { (2009), Lumpkin et } \\
\text { al. (2009). }\end{array}$ \\
\hline Innovativeness & $\begin{array}{l}\text { Creative in using resources } \\
\text { Develop new product } \\
\text { Emphasis on R and D } \\
\text { Many new lines of new products } \\
\text { Changes in product }\end{array}$ & $\begin{array}{l}\text { Kropp et al., (2008), } \\
\text { Fang et al., (2008), } \\
\text { Lumpkin et al. } \\
\text { (2009). }\end{array}$ \\
\hline Proactive & $\begin{array}{l}\text { Initiates actions to which competitors then respond. } \\
\text { A competitive "undo-the-competitors" posture } \\
\text { The first business to introduce new products/services } \\
\text { Get "right people" to identify market trends } \\
\text { Avoid competitive clashes (R) } \\
\text { To "follow the leader" in introducing new products (R). }\end{array}$ & $\begin{array}{l}\text { Kropp et al., (2008), } \\
\text { Lumpkin et al. } \\
\text { (2009). }\end{array}$ \\
\hline Aggressiveness & $\begin{array}{l}\text { Very aggressive and intensively competitive to take } \\
\text { business from the competition. } \\
\text { Make no special effort to take business from the } \\
\text { competition (R). } \\
\text { Adopts a bold, aggressive posture to exploit potential } \\
\text { opportunities. }\end{array}$ & $\begin{array}{l}\text { Lumpkin et al. } \\
\text { (2009) }\end{array}$ \\
\hline
\end{tabular}

Source: authors' tabulation from various sources 


\section{Social Capital}

The central proposition of social capital theory is that networks of relationships constitute a valuable resource (Putnam 2000; Oldroyd and Morris 2012). Social capital goes beyond ordinary networks. Broadbridge (2010) highlights that social capital prevails when network become a key resource for grasping opportunities and benefits. Bernades (2010) indicates that network-relationalembededness represents the degree of closeness and reciprocity between a focal firm and its relevant supply networks. The network, norms and trust play pivotal roles in facilitating information sharing, collective decision-making, and collective action (Wolz et al., 2011). Hence, social capital is expected to be able to enhance organization culture (Lin and Steven 2010).

From the enterprise perspective, social capital can be defined as investment in social relations with expected returns in the marketplace (Berzina 2011). Social capital can be a major key for firm performance through innovation as well as supply management channel (Alguezaui and Filieri 2010; Bernades 2010). Social capital at the firm level has a significant influence on both knowledge acquisition and innovation, which part of marketing capacity (Martínez-Cañas et al., 2012). In addition, Lim and Putnam (2010) indicate that social capital is associated with life satisfaction. However, Pirolo and Presutti (2010) notice the negative link between the development of strong ties and the growth of a start-up's innovation performance. Bernades (2010) points out that social capital affects on firm performance with complexity development of social capital.

Social capital at the firm level has a significant influence on both knowledge acquisition and innovation, which part of marketing capacity (Martínez-Cañas et al., 2012). However, Pirolo and Presutti (2010) notice the negative link between the development of strong ties and the growth of a start-up's innovation performance. Bernades (2010) points out that social capital affects on firm performance with complexity development of social capital. Ahmadi (2011) indicate that the link between social capital of the community and innovation performance of the SMEs doesn't seem to be straightforward on account of absorptive capacity. In social capital while social capital can be a major key for firm performance through innovation as well as supply management channel (Alguezaui and Filieri 2010; Bernades 2010).

The role of social capital in firm performance is dynamic at different phases within the organizational growth. Ahmadi (2011) indicate that the link between social capital of the community and innovation performance of the SMEs doesn't seem to be straightforward on account of absorptive capacity. In social capital while social capital can be a major key for firm performance through innovation as well as supply management channel (Alguezaui and Filieri 2010; Bernades 2010). There are many ways to explore social capital. Entrepreneurial social capital constitutes three 
elements: view of networks, which closely related to entrepreneurial social networks; view of resource, which is about resource-based management, and view of integration, which refers to shared resourced with common goal (Wang and Shi 2012). Warner (2012) draws distinction between internal and external focus in social capital. The external focus can be supply chain relationship, which lay on trust. From the internal perspectives, Gupta et al. (2011) outlines seven elements of internal focus in social capital, i.e. shared vision, cohesion, and trust. Another approach considers social capital constitutes three dimensions, i.e. structural, relational, and cognitive dimensions (Wu 2009; Mačerinskienė and Aleknavičiūtè 2011).

\section{Entrepreneurial Orientation and Pricing Strategy}

Researches on the impact of entrepreneurial orientation on pricing strategy are few. Although the direct impact is not precisely examines in most empirical studies, the indirect impacts are pictured in at least five researches. A study by Keh et al. (2007) is one of the prominent studies on the relationship, using the case of Singapore. The study shows the importance of entrepreneurial orientation in increasing firms' performance, which can be measured under pricing strategy. Hartsfield et al. (2008) is another empirical study on the relationship between entrepreneurial orientation and firms' performance. The finding suggests that entrepreneurial orientation is an important antecedent factor on the observed firms' performance. The entrepreneurial orientation in the forms of risk taking and competitive aggressiveness has been key factors increasing small firm performance, as suggested by Lechner and Gudmundsson (2012). Amongst all, Eggers et al. (2012) is the one that directly shows the relationship between entrepreneurship orientation and marketing strategy, with a finding that innovation is a key entrepreneurial orientation in enhancing marketing strategy for small firms. In addition, Verhees et al. (2012) supports the argument that entrepreneurial orientation closely affects strategic marketing choices.

\section{Social Capital and Pricing Strategy}

Studies on the relationship between social capital and pricing strategy are sparse. A study that relates social capital on competitive advantage as one of measurements for pricing strategy, suggests a utilization of corporate social responsibility (CSR) in improving profitability (Saeed and Arshad 2012). Under another spectrum of pricing strategy, Starkey and Tempest (2004) shows that social capital is a pivot factor in strategic management. In addition, Castro et al. (2015) find that social capital affects the international market share of 225 global contractors. Focusing on entrepreneurial firms, Autio et al. (2005) suggest an evidence of social capital in foreign market learning process. 


\section{RESEARCH METHOD}

The research applies a mix method, which using both qualitative and quantitative approaches. The decision in using the mix method for this study is to provide a holistic view on the impact of entrepreneurship orientation and social capital on pricing strategy in small enterprises. A quantitative method enables researchers to find indication of a statistical relationship from entrepreneurship orientation and social capital on pricing strategy. A qualitative method enables researchers to dig deeper through the interaction with the owners of firms in finding the relationship between entrepreneurship orientation and social capital to pricing strategy. The quantitative approach involves validity test, reliability test, and exploratory factor analysis using Kaiser-Meyer Olkin index, Bartlett's test of sphericity, and confirmatory factor analysis. The qualitative approach involves interview, narrative (transcribing), and coding. The following is the brief description of the methods.

\section{Quantitative Approach}

When data are obtained from questionnaires, the data are analysis by following three steps. The first step is to check validity of the result from questionnaires using the validity test. The test refers to item analysis, for example, difficulty and discrimination index. To make sure that the questionnaires meet the validity requirement, three steps are involved (i.e. content validity, face validity, and construct validity). The second step is a test for the reliability of the measurements under Cronbach's alpha. The third step is exploratory factor analysis.

\section{Exploratory Factor Analysis}

Exploratory factor analysis is used to identify the underlying factors or latent variables for a set of variables. Exploratory factor analysis is based on the common factor model, where each observed variable is a linear function of one or more common factors (i.e., error-or item specific information) Harrington (2008). Furthermore, the analysis is supported by several test which are Kaiser-Meyer Olkin (KMO), Bartlett's test of sphericity and exploratory factor analysis itself. KMO is an index value that is used to test the accuracy of factor analysis. Bartlett's test is used to test if $\mathrm{k}$ samples have equal variances. Cramer and Howitt (2004) highlight that the test which is aimed to identify simultaneously problem among the variables, which one of assumption in regression method. Confirmatory factor analysis (CFA) aims to assess overall fit of the entire measurement model and to obtain the final estimates of the measurement model parameters.

This study employs linear regression in estimating the effect of entrepreneurial orientation and social capital on pricing strategy. The method of regression is ordinary least squared (OLS). The model can be expressed as followed: 


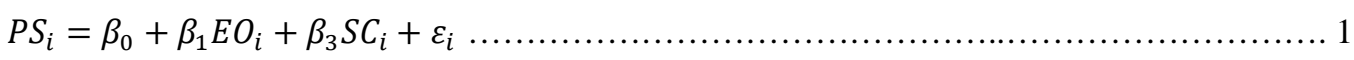

For PS is pricing strategy; EO is entrepreneurial orientation; SC is social capital; $\beta_{1}$, $\beta_{2}$ and $\beta_{3}$ are parameters to be estimated; $\varepsilon$ is disturbance variable; $i$ is the $i$-th firm.

As the measurements for entrepreneurial orientation are varied, this study adopts 5 measurements. The five measurements are aggressiveness of innovation process (EO1), aggressiveness of innovation process (EO2), aggressiveness to deal with competitors (EO3), autonomy (EO4), and risk taker (EO5). The same also applies to social capital, which can be measured using four measurements, i.e. staff relationship (SC1), supplier relationship (SC2), goal sharing (SC3), and distribution (SC4). Hence, the model can be modified into:

$P S_{i}=\beta_{0}+\gamma_{1} E O 1_{i}+\gamma_{2} E O 2_{i}+\gamma_{3} E O 3_{i}+\gamma_{4} E O 4_{i}+\gamma_{5} E O 5_{i}+\delta_{1} S C 1_{i}+\delta_{2} S C 2_{i}+\delta_{3} S C 3_{i}+$

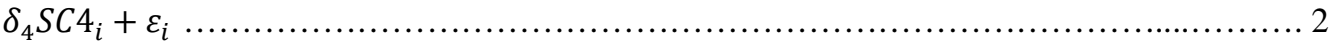

\section{Qualitative Approach}

The author conducted interview process in this research with a research assistant to ensure that both would have a first-person understanding of the interview so as to facilitate the subsequent analysis. The interviews were conducted in the offices of the interviewees or at venues designated by them. An interview began with introducing and explaining the purpose of the interview, asking the interviewee's permission for voice recording, and a few general questions in order to establish a brief understanding of the nature, start-up and development of the business. The focus of the interview was on exploring the critical incidents in which learning has occurred during the stages of planning, launching, developing, and managing the business through asking a number of open-ended questions. For example, one of the key questions was: "When you launched your business, were there any particular events or moments in which you have learnt something critical? You may illustrate either positive or negative examples”.

\section{Qualitative Analysis}

A variety of textual forms provide a basis for interpretation, such as recorded and transcribed interviews, notes of observations, transcribed conversations, speeches, and archival documents. Generally, the interpreter relies on some form of thematic, content-based analysis (Kleinberg and Easley 2010). The interpretive ethnographer tries to understand cultural knowledge through the "lived experience" of the observed community helps guide observed recurrent, patterned cultural behavior (Yagi and Kleinberg 2010). Furthermore, the steps conducted in qualitative analysis were storytelling, narrative and coding.

\section{Sampling Method and Data}

This study uses the same data set as Suyanto and Pratono (2014). The unit of analysis is small enterprises. As stated in Suyanto and Pratono (2014), the term of 'small enterprises' refers to companies with asset less than Rp500 Million and sales 
less than Rp2.5 Billion as Law No. 20, which was enacted in 2008. Using random sampling approach, this study takes the location of sampling in Surabaya. The population of small businesses in Surabaya in 2012 as published by Central Bureau of Statistics was 362.448 units. Using the methods for calculating sampling, so the ideal sample size is 380 enterprises. This research project observes 168 enterprises, which represent the same characteristic of the sample with population. The observed enterprises represent the key players of small enterprises and, hence, provides a close picture to the ideal samples, as shown in Suyanto and Pratono (2014) that replicated in Table 2.

In order to identify that the selected firms are small enterprises, the secondary data from Central Bureau of Statistics (BPS) is used as the prior information. During the interview process, there are one firm among the 168 observed firms are no longer small firms, as the amount of assets has risen to more than Rp500 Million or the sales has increase to more than Rp2.5 Billion. That firm is included in the analysis with consideration that the assets or sales is not significant larger than the other firms, so that the statistical results with still unbiased.

Table 2

Descriptive data

\begin{tabular}{lcc}
\hline Groups & Frequency & $\mathbf{\%}$ \\
\hline Trading & 66 & 39.3 \\
Manufacture & 50 & 29.8 \\
Construction & 16 & 9.5 \\
Services & 36 & 21.4 \\
\hline Source: authors' calculation from the collected samples
\end{tabular}

The data are mostly collected in Surabaya, a city with population of around 3.5 million. The main economic activities indicate that many enterprises become core business in trading, manufacture, services and construction sectors. The data showed that sample represents two major sectors, i.e. trading and manufacturing (Table 1). These two sectors cover 69 percent of the samples. Services are accounted for 21.4 percent of the total samples, while the construction sector has a proportion of 9.5 percent.

\section{RESULTS}

\section{The Quantitative Results}

The quantitative analysis is divided into three parts, analysis of the reliability test, factor analysis, and regression analysis.

\section{Results from Reliability Test}

The results of reliability tests are presented in Table 3. The Cronbach's alpha (CA) coefficients shows that variables of pricing capability and social capital have 
items with an underlying (or latent) construct, as the coefficient is higher than 0.600 (the minimum requirement level of CA test). In contrast, entrepreneurial orientation variable has poor reliability; as the coefficient Cronbach's alpha is lower than 0.600. One might need to bear in mind that the high alpha doesn't directly imply that the measure is unidimensional. CA coefficient shows only reliability.

Table 3

Estimation Results of Reliability Test

\begin{tabular}{lcc}
\hline \multicolumn{1}{c}{ Variables } & Cronbach's Alpha & Number of Items \\
\hline Pricing Capability & 0.780 & 13 \\
Social Capital & 0.647 & 28 \\
Entrepreneurial Orientation & 0.382 & 24 \\
Overall & 0.731 & 65
\end{tabular}

Source: Authors' calculation from data in questionnaires.

\section{Results from Factor analysis}

Results from factor analysis are presented in Table 3. After removing some items with factor loading less than 0.500 , the factor analysis shows that each latent variable has at least three or two items and comes up with new factors. The pattern of market power refers to capability of setting price for new products, which comprises into four items (P21, P12, P23 and P24), while the other items (P11, P32, P13) are considered as pattern of relationship with customers. The rest of the pricing strategy items refers to pattern of marketing program (P34, P33, P22, P31).

Each item in pricing strategy for the three patterns is recorded in Table 4.

Table 4

Pricing Strategy

\begin{tabular}{lcll}
\hline Code & $\begin{array}{c}\text { Factor } \\
\text { Loading }\end{array}$ & \multicolumn{1}{c}{ Items } & \multicolumn{1}{c}{ Patterns } \\
\hline P21 & 0.701 & Produced new product(s) this year. & $\begin{array}{l}\text { Capability of setting price } \\
\text { for new products. }\end{array}$ \\
P12 & 0.571 & Setting competitive price. & \\
P23 & 0.725 & Our new products were successful. & \\
P24 & 0.563 & We sold our new product successfully. & \\
& & Communication with \\
P11 & 0.689 & We respond competitors' pricing tactic. & customers. \\
P32 & 0.592 & We have public communication skill. \\
P13 & 0.684 & We informs the cost structure to our & \\
& & customers. & \\
\hline
\end{tabular}


Table 4 (Continued)

Pricing Strategy

\begin{tabular}{ccll}
\hline Code & $\begin{array}{c}\text { Factor } \\
\text { Loading }\end{array}$ & \multicolumn{1}{c}{ Items } & \multicolumn{1}{c}{ Patterns } \\
\hline P34 & 0.639 & Involved in marketing training. & Marketing program. \\
P33 & 0.726 & Developing brand. & \\
P22 & 0.775 & Developing new products with R\&D. & \\
P31 & 0.739 & Developing advertising program. & \\
\hline
\end{tabular}

Source: authors’ calculation from questionnaires.

Next step is factor analysis on items for social capital variables. With higher level of KMO of 0.689, factor analysis on social capital indicates discerned regularities and order in phenomena. These co-occurring phenomena are independent of each other; there are four distinct patterns. The first pattern called as staff relationship, the second one refers to relationship with suppliers, the third is associated with goal sharing among the workers, and the fourth is related to distribution channel. Table 5 shows the value of factor loading for each item of the social capital.

Table 5

Social Capital

\begin{tabular}{|c|c|c|c|}
\hline Code & $\begin{array}{l}\text { Factor } \\
\text { Loading }\end{array}$ & Items & Patterns \\
\hline S51 & 0.621 & Our staffs help among those who have problems. & Staff relationship. \\
\hline S52 & 0.735 & Our staffs have integrity. & \\
\hline S53 & 0.758 & Our staffs are friendship. & \\
\hline S61 & 0.536 & Our staffs are eager to achieve the goal of our firm. & \\
\hline S63 & 0.722 & Our staffs understand the vision of our company. & \\
\hline S13 & -0.649 & Our firm relies on flexible supplier in operation. & Supplier relationship \\
\hline S31 & 0.757 & Our firm builds relationship to reliable suppliers. & \\
\hline S32 & 0.791 & $\begin{array}{l}\text { Our firm builds relationship to suppliers who have } \\
\text { ability to manage asset as our request. }\end{array}$ & \\
\hline.$S 44$ & 0.746 & Our staffs share their dream. & Goal sharing. \\
\hline S64 & 0.669 & Our firm has ideal goal. & \\
\hline S65 & 0.661 & Our staffs understand the target. & \\
\hline S11 & 0.678 & Our firm relies on one supplier. & Distribution. \\
\hline S24 & 0.718 & $\begin{array}{l}\text { Our firm relies on other company to manage on } \\
\text { time distribution. }\end{array}$ & \\
\hline
\end{tabular}

Source: authors’ calculation from questionnaires. 
Factor loading for entrepreneurship orientation variables is presented in Table 6. The highest KMO value is for variable EO07, with the value of 0.739 . The entrepreneurship orientation variables can be grouped into five district patterns. The first pattern is named as proactivity of innovation process. The second pattern is aggressiveness of innovation process, while the third pattern is related to aggressiveness to deal with competitors. The fourth pattern is a variable explaining the autonomy of the owners, the risk taker, and proactive behavior. The fifth pattern is representing autonomy with risk taker.

Table 6

Entrepreneurial Orientation

\begin{tabular}{|c|c|c|c|}
\hline Code & $\begin{array}{l}\text { Factor } \\
\text { Loading }\end{array}$ & Items & Patterns \\
\hline EO32 & 0.673 & Over the last year, our firm has no new product. & \multirow{5}{*}{$\begin{array}{l}\text { Proactivity of } \\
\text { innovation process. }\end{array}$} \\
\hline EO03 & -0.561 & Our staffs don't depend too much on the manager. & \\
\hline EO31 & 0.581 & $\begin{array}{l}\text { In our firm, marketing is more important than } \\
\text { innovation. }\end{array}$ & \\
\hline EO33 & 0.678 & $\begin{array}{l}\text { Our product has a bit differences from the previous } \\
\text { one. }\end{array}$ & \\
\hline EO44 & 0.571 & We avoid conflict with competitors. & \\
\hline EO04 & 0.564 & Our owner manager sets the target to our employees. & \multirow{4}{*}{$\begin{array}{l}\text { Aggressiveness of } \\
\text { innovation process. }\end{array}$} \\
\hline EO34 & 0.645 & Our firm never copies the solution from competitors. & \\
\hline EO35 & 0.667 & $\begin{array}{l}\text { Our firm prefers to establish new method than copy } \\
\text { from others. }\end{array}$ & \\
\hline EO53 & 0.667 & $\begin{array}{l}\text { Our firm creates the first idea, then followed by } \\
\text { competitors. }\end{array}$ & \\
\hline EO52 & 0.667 & Our firm is quite aggressive to seize opportunity. & \multirow{3}{*}{$\begin{array}{l}\text { Aggressiveness to dea } \\
\text { with competitor. }\end{array}$} \\
\hline EO41 & -0.823 & Our firm responds to what the competitors did. & \\
\hline EO43 & 0.665 & Our firm is using a new technology this year. & \\
\hline EO07 & 0.739 & Owner manager plays pivotal role to seize opportunity. & \multirow{3}{*}{$\begin{array}{l}\text { Autonomy, risk taker, } \\
\text { proactive. }\end{array}$} \\
\hline EO21 & 0.601 & Our firm tries to avoid risk. & \\
\hline EO45 & 0.679 & Our new products follow the market trend. & \\
\hline EO01 & 0.602 & In our firm, supervisor from senior staff is important. & \multirow{3}{*}{$\begin{array}{l}\text { Autonomy with risk } \\
\text { taker. }\end{array}$} \\
\hline EO24 & 0.703 & $\begin{array}{l}\text { Our firm is flexible to provide resource to deal with } \\
\text { problems. }\end{array}$ & \\
\hline EO22 & -0.632 & Our firm is running naturally. & \\
\hline
\end{tabular}

Source: authors' calculation from questionnaires.

\section{Regression Analysis}

The result of regression analysis on the market power of SMEs in East Java is presented in Table 6. The market power is measured using three variables: the 
capacity of setting price for new products (MC1), the communication with customers (MC2), and marketing program (MC3). These three variables are estimated separately under three different equations, and the estimates are presented in Table 7.

In the first model with capability of setting price for new products as a measure for market power (dependent variable), the aggressiveness in innovation process (EO2) has a positive significant effect on market power. The same also picture in the autonomy with risk taker (EO5), which has a positive and significant effect. A good relationship with distributors (SC4) also provides a positive significant effect to the capability of setting price for new products. This model has goodness of fit (R) of 0.56 , which is a little bit greater than other two models.

Table 7

Regression Result

\begin{tabular}{lccc}
\hline \multicolumn{1}{c}{ Variables } & $\begin{array}{c}\text { Model 1: } \\
\text { MC 1 }\end{array}$ & $\begin{array}{c}\text { Model 2: } \\
\text { MC 2 }\end{array}$ & $\begin{array}{c}\text { Model 3: } \\
\text { MC 3 }\end{array}$ \\
\hline Constant & -1.595 & 2.349 & 3.496 \\
EO1 & -0.072 & 0.082 & 0.005 \\
EO2 & 0.377 & 0.088 & 0.062 \\
EO3 & 0.254 & 0.224 & -0.153 \\
EO4 & 0.129 & -0.151 & -0.174 \\
EO5 & 0.342 & 0.153 & 0.011 \\
SC1 & 0.110 & -0.033 & -0.117 \\
SC2 & -0.203 & -0.222 & 0.183 \\
SC3 & 0.202 & 0.232 & 0.202 \\
SC4 & 0.185 & -0.051 & 0.076 \\
\hline R & 0.560 & 0.443 & 0.350 \\
R-Squared & 0.310 & 0.196 & 0.122 \\
\hline Note: MC1 is the capability of setting price for new products; MC2 is \\
communication with customers; MC3 is marketing program.
\end{tabular}

Model 2 highlights the communication with customers as a measure for market power (the dependent variable). The estimation result indicates that social capital plays important roles in market power. The relationship with supplier (SC2) has a negative effect on communication with customers. This finding is contradicting the conventional belief that good relationship with suppliers might increase communication with customers (supply chain), as noted by Alguezaui and Filieri (2010) and Bernades (2010). However, the finding is in line with Ahmadi (2011) that the complexity of social capital in SMEs doesn't seem to be straight forward influencing the market power. In contrast, the goal sharing among workers within a firm (S4) has a positive and significant impact on the communication to customers. This finding implies that if all workers share the same vision, then the relationship from firm to customers can maintain positively, which is in line with arguments by Martínez-Cañas et al. (2012). 
Estimates from model 3 in the last column of Table 7 show that both entrepreneur orientation (EO) and social capital (SC) play important roles on marketing program. The entrepreneur orientation variables that have important effect on marketing program are aggressiveness of innovation process (E2) and autonomy with risk taker (E5). The social capital variable that has positive and significant effect on marketing program is goal sharing (S3).

\section{The Qualitative Results}

\section{Pricing Strategy}

The interpretative approach indicates that capability of the observed firms to set a price is quite low. The observed respondents prefer competitiveness price to seize business opportunity. The first respondent highlight that setting higher price is not the nature of his firm.

"Apparently, our firm focuses on customer satisfaction through providing products with best quality and the most competitive price.

Our customers will not be happy if the price increases".

Another respondent also argues that

"Instead of increasing the price, we prefer to provide discount to our loyal customers. They really hate increased price”.

This result indicates that price reduction still plays pivotal role recently. However, there are some other possibilities from transfer pricing to denying cartel price.

"I would rather to say that price of our input is the one which determines our increased price”.

Price coordination becomes apparent in which merchant association aims to facilitate interaction with governments. Fjell et al. (2010) highlight interdependence among firms occurs on pricing strategy.

"Price competitiveness is nature of our business. Our customers are very sensitive to our prices. So we need to provide price competitiveness to fight for competitive advantage".

The observed firms base their intra-company trade on cost-based transfer prices. Regarding capability to set price, this interview indicates high dependency of the observed firms to main supplier. Pfeiffer et al (2011) consider transfer cost from supplier with cost-based pricing method, which refers to the total cost is added (as income or profit) to the cost of the product to arrive at its selling price.

\section{Social Capital}

According to an SME owner, social capital is associated with staff relationship, which is considered to be structural element. 
"Our staffs have close relationship. Every long weekend, we arrange outing activities as a family gathering “.

This network structure refers to Broadbridge (2010), who indicates that direct ties in which people close to individual.

\section{Aggressiveness in Entrepreneurial Orientation}

"I would rather to avoid conflict with our competitors. However, the decision to take aggressive position depends on the situation, such as the way our competitors treat us".

This indicates that aggressiveness is not a nature of entrepreneurial orientation of the observed firms. This idea refers to hawk-dove game theory, as showed in Varian (2010). The game of chicken, also known as the hawk-dove game or snow-drift game, is an influential model of conflict for two players in game theory. The principle of the game is that while each player prefers not to yield to the other, the worst possible outcome occurs when both players do not yield.

\section{Discussion}

The quantitative results under the regression analysis suggests that the impacts of entreprenerial orientation and social capital on pricing strategy are very pivotal. The impacts can be traced through three channels. The first channel is price setting capacity, the second channel is communication with customers, and the third channel is marketing program.

Based on the results in Table 7 Model 1, price setting capacity is importantly influenced by entrepreneurial orientation (under two measures, namely aggresiveness in innovation process and autonomy with risk taker) and social capital (under a measure, namely a good relationship with distributors). This finding suggests that price setting capacity of small enterprises in East Java significantly depends on innovation process, autonomy, and relationship with distributors. In other words, aggresiveness in innovation process and autonomy with risk taker becomes two important measures of entrepreneurial orientation in influencing price setting capacity, while a good relationship with distributors is a measure of social capital in enhancing price setting capacity. Although studies on the impacts of entreprenerial orientasi on pricing strategy that specifically focus on innovation process or autonomy are hardly to find, the outcomes of this current study is in line with Keh et al. (2007) and Hartsfield et al. (2008). In edition, the finding of this study on the effect of good relationship with distributors on pricing strategy is closely similar to Castro et al. (2015) and Autio et al. (2005), although the measure of pricing strategy between these studies is different with the current study.

The second channel, communication with customers, is affected only by social capital (Model 2 in Table 7). Two measures of social capital, namely relationship with suppliers and goals sharing among workers, is found to have 
significant impact on communication with customers. A strong relationship with suppliers reduces the ability of small firms to communicate with customers. This finding is contradicting the conventional wisdom of supply chain as highlighted by Alguezaui and Filieri (2010) and Bernades (2010). However, the finding supports Ahmadi (2011) argument that the complexity of social capital in SMEs doesn't seem to be straight forward influencing the market power. Furthermore, goals sharing among workers encourage workers to be more communicative with customers. The finding supports the argument of Martínez-Cañas et al. (2012).

Marketing program, as the third channel for pricing strategy, is found to be influenced by aggressiveness of innovation process and autonomy with risk taker (two measures for entrepreneur orientation) and goal sharing (a measure for social capital). The positive effect of entreprenurial orientation on pricing strategy found in this current study support findings in Eggers et al. (2012) and Verhees et al. (2012). In addition, goal sharing among workers enhances strategy in marketing program, which is in line with Castro et al. (2015) and Autio et al. (2005).

From the three channels of pricing strategy, the findings suggest the evidence of entreprenerial orientasi and social capital in influencing pricing strategy. The evidence contributes to the literature of entreprenerial orientation and sociall capital, in particular those focusing in small enterprises in Indonesia.

The results of qualitative analysis complements the quantitatif findings by showing a different spectrum. Small firms in East Java are found to set a low price in competition. The price setting strategy focuses on low price. This qualitative results indicate that small firms tend to set price on cost-based consideration, as pointed out by Liozu et al. (2012). Consumer loyalty becomes an important aspect mentioned in the interview with the small firms' owners. The loyalty from customers is highligted in Piercy et al. (2010) and this current study supports this argument. In addition, price sensitivity has been considered by small firms in setting the price. They tend to avoid increasing price due to the sensitive demand function.

From the entreprenerial orientation, the qualitative findings indicate that the small firms tend to avoid direct competition with competitors. The aggresiveness in innovation process mainly depend on the competitors. In other words, the aggresiveness of small firms is a reaction from the competitors. This results can be seen through the oligopolistic market indicated in price leadership competition of Stackelberg (2011). In this case, small firms behave as a followers, while large firms is the price leader. The hawk-dove game in Varian (2010) could be applied for this type of competition.

The qualitative results with regard to social capital highlight the importance of networking. The strong relationship between owner and worker and among workers are the pivot aspect of social capital. This finding justifies the importance of network structure in Broadbridge (2010) and Jansen et al. (2011). This qualitative 
result complement the findings in qualitative analysis showing that a strong relationship that built in a small firm can be an important aspect in increasing the social capital of the firms, which in turn increase the ability to set price.

\section{CONCLUSION AND SUGGESTION}

\section{Conclusion}

Three important conclusions can be drawn from the analysis.

1. Market power or ability to set price is a sensitive issue among the observed small medium firms. The firms refuse to admit that they have market power for some reasons. Firstly, the way a firm raise price will devastate their consumers. They would rather to argue that they try to decrease the price for their consumer satisfaction. In fact, the prices never go down but keep on increasing. Secondly, when firms increase the price, they argue transfer-cost based pricing, such as expected oil price or transport cost, as the main reason to increase their prices.

2. Market power is specifically associated with one of the competitive advantage elements, namely bargaining power with buyers. Moreover, the relationship between social capital and market power is unique. This current research provides evident that relationship with distributors (SC4) has positive impact on market power. Even when the service provider can't immediately fix the problem, customers can tolerate it if the employee explains to them the problem in a good manner. The employee needs to provide excellent service to the customers.

3. Among the elements of entrepreneurial orientation, there are two main concepts which affect on market power, which are aggressiveness to deal with competitor and autonomy with risk taker. Unless a firm takes aggressive position, poor market power will come to a place and the firm follows other. Autonomy to the front liner staff also determines to the market power with a risk of consumer satisfaction.

4. The qualitative analysis concludes that the main price strategy is price reduction, maintenance of independence among firms, providing discounts, close relationship among staffs, and avoiding conflicts with competitors. A close relationship among staffs reflects a social capital in the observed firms, while avoiding conflicts with competitors is one of the key entrepreneurial orientations.

\section{Suggestion}

The suggestion of this research based on the results is that social capital is essential for market power, which indicates that SMEs must enhance specific networks. The following is the detailed suggestions for the stakeholders.

For policy makers who aim to promote affordable price to customers or strengthen the market power of SMEs, the chain networks management needs to be 
taken into account. The networks with distributors and supplier play pivotal role to the market power of SMEs. Unless the public can handle this chain, the possibility of cartel price will remain high.

Among the SME managers who are eager to strengthen their market power, building a strong relationship with distributor is the most challenging to foster market power. The relationship has advantages and disadvantages for the SMEs since the hawk-dove game embedded in such relationship. It appears that once a party takes advantages for short-term benefit, the long run opportunities will be missed.

For scholars who are interested in social capital and market power, it is appear that social capital has limitation to strengthen market power. Hence, the future research can handle the extent to which firms can manage social capital, which enable to strengthen the market power. The future research with aim to measure market power should take into account the sensitive issue in which the consumers disregard anyone who has market power.

\section{REFERENCES}

Ahmadi, A. A. 2011. Social capital for knowledge management. Interdiciplinary Journal of Contemporary Research Business. Vol.3 No.7: 957-972.

Alguezaui, S., and R. Filieri. 2010. Investigating the role of social capital in innovation: sparse versus dense network. Journal of Knowledge Management. Vol.14 No.6: 891-909.

Al-Swidi, A. K., and R. Mahmood. 2012. Total quality management, entrepreneurial orientation and organizational performance: the role of organizational culture. African Journal of Business Management. Vol.6 No.13: 4717-4727.

Autio, E., H. J. Sapienza, and P. Arenius. 2005. International Social Capital, Technology Sharing, and Foreign Market Learning in Internationalizing Entrepreneurial Firms. United Kingdom: Emerald Group Publishing Limited.

Bernades, E. S. 2010. The effect of supply management on aspects of social capital and the impact on performance: a social network perspective. Journal of Supply Chain Management. Vol.46 No.1: 45-56.

Bertta, M., R. Jones, and J. Latham. 2010. Entrepreneurship and the innovative self: a Schumpeterian reflection. International Journal of Entrepreneurial Behaviour and Research. Vol.16 No.3: 229 - 244.

Berzina, K. 2011. Enterprise related to social capital: different level of social capital accumulation. Economics and Sociology. Vol.4 No.2: 66-83.

Broadbridge, A. 2010. Social capital, gender and careers: evidence from retail senior 
managers. Equality, Diversity and Inclusion: An International Journal. Vol.29 No.8: 2040-7149.

Carney, M., E. R. Gedajlovic, P. P. M. A. R. Heugens, M. V. Essen, and J. V. Oosterhout. 2011. Business group affiliation, performance, context, and strategy: a meta-analysis. Academy of Management Journal. Vol.54 No.3: 437-460.

Castro, I., F. J. Acedo, and A. Picon-Berjoyo. 2015. Social capital configuration and the contingent value of the cross-national diversity: a multi-group analysis. Revista Europea de Direccion y Economia de la Empresa. Vol.24 No.1: 2-12.

Covin, J. G., and W. J. Wales. 2012. The measurement of entrepreneurial orientation. Entrepreneurship Theory and Practice. Vol.36 No.4: 677-702.

Cramer, D., and D. L. Howitt. 2004. The Sage Dictionary Of Statistics: A Practical Resource for Students in the Social Sciences. United Kingdom: SAGE Publishing.

Eggers, F., D. J. Hansen, and A. E. Davis. 2012. Examining the relationship between customer and entrepreneurial orientation on nascent firms' marketing strategy. International Entrepreneurship and Management Journal. Vol.8 No.2: 203-222.

Fang, T., V. Worm, and R. L. Tung. 2008. Changing success and failure factors in business negotiations with the PRC. International Business Review. Vol.17: 159-169.

Gupta, V. K., R. Huang, and A. A. Yayla. 2011. Social capital, collective transformation leadership, and performance: a resource-based view of selfmanaged teams. Journal of Managerial Issues. Vol.23 No.1: 31-45.

Gurbuz, G., and S. Aykol. 2009. Entrepreneurial management, entrepreneurial orientation and Turkish small firm growth. Management Research News. Vol.32 No.4: 321-336.

Harrington, D. 2008. Confirmatory Factor Analysis. Oxford, United Kingdom: Oxford University Press.

Hartsfield, S., D. Johansen, and G. Knight. 2008. Entrepreneurial orientation, stragety, and marketing capabilities in the performance of born global firms. International Business Research Teaching and Practice. Vol.2 No.1: 12-38.

Kartono, B. 2011. Manufacturer-retailer pricing competition across multiple product categories: an equilibrium framework. Journal of Applied Business and Economics. Vol.12 No.2: 27-39.

Keh, H. T., T. T. Nguyen, and H. P. Ng. 2007. The Effects of entrepreneurial orientation and marketing information on the performance of SMEs. Journal 
of Business Venturing. Vol.22 No.4: 592-611.

Kleinberg, J., and D. Easley. 2010. Networks, Crowds, and Markets: Reasoning About a Highly Connected World. Cambridge, UK: Cambridge University Press.

Kropp, F., N. J. Lindsay, and A. Shoham. 2008. Entrepreneurial orientation and international entrepreneurial business venture startup. International Journal of Entrepreneurial Behavior and Research. Vol.14 No.2: 102-117.

Laforet S. 2009. Effect of size, market and strategic orientation on innovation in nonhigh-tech manufacturing SMEs. European Journal of Marketing. Vol.42 No.1: 188-212.

Lechner, C., and S. V. Gudmundsson. 2014. Entrepreneurial orientation, firm strategy and small firm performance. International Small Business Journal. Vol.32 No.1: 36-60.

Lim, C., and R. Putnam. 2010. Religion, social networks and life satisfaction. American Sociological Review. Vol.75 No.6: 914-933.

Limehouse, F. F., T. M. Michael, and K. W. Rotthoff. 2012. Peak-load verse discrimination pricing: evidence from the golf industry. Review of Industrial Organization. Vol.40 No.3: 151-165.

Liozu, S. M., A. Hinterhuber, R. Boland, and S. Pereli. 2012. The conceptualization of value-based pricing in industrial firms. Journal of Revenue dan Pricing Management. Vol.11 No.1: 12-34.

Liozu, S.M., and A. Hinterhuber. 2013. Pricing orientation, pricing capabilities, and firm performance. Management Decision. Vol.51 No.3: 594-614.

Lin, J. and S. Steven. 2010. Can Guanxi be a problem? Contexts, ties, and some unfavorable consequences of social capital in China. Asia Pacific Journal of Management. Vol.27 No.3: 561-581.

Liu, Q. and D. Zhang. 2013. Dynamic pricing competition with strategic customers under vertical product differentiation. Management Science. Vol.59 No.1: 84101.

Lumpkin, G. T., C. C. Cogliser, and D. R. Schenider. 2009. Understanding and measuring autonomy: an entrepreneurial orientation perspective. Entrepreneurship Theory and Practice. Vol.33. No.1: 47-69.

Mačerinskienè, I., and G. Aleknavičiūtè. 2011. The evaluation of social capital benefits: enterprise level. Business, Management and Education. Vol.9 No.1: 109-126.

Martínez-Cañas, R., F. J. Sáez-Martínez, and P. Ruiz-Palomino. 2012. Knowledge acquisition's mediation of social capital-firm innovation. Journal of 
Knowledge Management. Vol. 16: 61 - 76.

Murray, J. Y., G. Y. Gao, and M. Kotabe. 2011. Market orientation and performance of export ventures: the process through marketing capabilities and competitive advantage. Journal of the Academic Marketing Science. Vol.39: 252-369.

Oldroyd, J. B., and S. S. Morris. 2012. Catching falling starts: a human resource response to social capital's detrimental effect of information overload on star employees. Academy of Management Review. Vol.37 No.3: 396-418.

Parkman I. D., S. S. Holloway, and S. S. Sebastiao. 2012. Creative industries: aligning entrepreneurial orientation and innovation capacity. Journal of Research in Marketing and Entrepreneurship. Vol.14 No.1: 95-114.

Pfeiffer, T., U. Schiller, and J. Wagner. 2011. Cost-based transfer pricing. Revenue Accounting Study. Vol.16: 219-246.

Piercy, N. F., D. W. Cravens, and N. Lane. 2010. Thinking strategically about pricing decisions. Journal of Business Strategy. Vol.31 No.5: 38-48.

Pirolo, L., and M. Presutti. 2010. The impact of social capital on the start-ups' performance growth. Journal of Small Business Management. Vol.48 No.2: 197-227.

Putnam, R. D. 2000. Bowling Alone: The Collapse and Revival of American Community. New York: Simon and Schuster.

Renko, M., A. Carsrud, and M. Brännback. 2009. The Effect of a market orientation, entrepreneurial orientation, and technological capability on innovativeness: a study of young biotechnology ventures in the United States and in Scandinavia. Journal of Small Business Management. Vol.47 No.3: 331-369.

Rubera, G., and A. H. Kirca. 2012. Firm innovativeness and its performance outcomes: a meta-analysis review and theoretical integration. Journal of Marketing. Vol.76 No.3: 130-147.

Saeed, M. M., and F. Arshad. 2012. Corporate social responsibility as a source of competitive advantage: the mediating role of social capital and reputational capital. Journal of Database Marketing and Customer Strategy Management. Vol.19 No.1: 219-232.

Starkey, K., dan S. Tempest. 2010. Bowling along: strategic management and social capital. European Management Review. Vol.1: 78-83.

Stackelberg, H. V. 2011. Market Structure and Equilibrium. New York: Springer.

Sundqvist, S., K. Kylaheiko, O. Kuivalainen, and J. W. Cadogan. 2012. Kirznerian and Schumpeterian entrepreneurial-oriented behavior in turbulent export markets. International Marketing Review. Vol.29 No.4: 494-509. 
Suyanto and A. H. Pratono. 2014. The Impact of entrepreneurship orientation, human capital, and social capital on innovation success of small firms in East Java. Jurnal Manajemen Teknologi (Indonesian Journal for the Science of Management). Vol.13 No.2: 117-125.

Varian, H. R. 2010. Intermediate Microeconomics: A Modern Approach. 8th Edition. New York: W. W. Norton and Company Inc..

Verhees, F. J., T. Lans, and J. A. Verstegen. 2012. The influence of market and entretreneurial orientation on strategic marketing choices: the cases of Dutch farmers and horticultural growers. Journal on Chain and Network Science. Vol.12 No.2: 167-179.

Wang, P., and W. Shi. 2012. Mechanism analysis of coal mine entrepreneurial social capital. Technology and Investment. Vol.3 No.3: 154-157.

Warner, S. K. 2012. Social Structure: Demographic Changes and the Well-Being of Older Persons. New York: Springer Publishing Company.

Wolz, A., J. Fritzsch, G. Buchenrieder, and A. Nedoborovsky. 2011. Does cooperation pay? The role of social capital among household plot farmers in Ukraine. South East European Journal of Economics and Business. Vol.5 No.2: 55-64.

Wu, D. 2009. Measuring performance in small and medium enterprises in the information and communication technology industries. Thesis of Philosophy Doctor at RMIT University. Unpublished.

Wu W., M. Chang, and C. Chen. 2008. Promoting innovation through the accumulation of intellectual capital, social capital, and entrepreneurial orientation. R\&D Management. Vol.38 No.3: 265-277.

Yagi, N., and J. Kleinberg. 2010. Boundary work: an interpretive ethnographic perspective on negotiating and leveraging cross-cultural identity. Journal of International Business Studies. Vol.42 No.5: 629-653. 